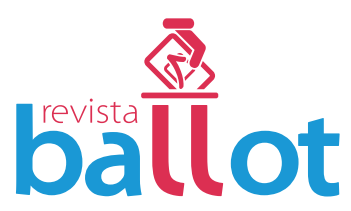

\title{
The banning of political parties in Spain (the Batasuna case)
}

\author{
Eduardo Vírgala Foruria (UPV, Espanha) \\ eduardo.virgala@ehu.es \\ Universidad del País Vasco \\ Euskal Herriko Unibertsitatea \\ Barrio Sarriena, s/n - 48940 \\ Leioa (Bizkaia)
}




\begin{abstract}
This article analyzes the constitutional and legal limits in Spain applicable to the creation and maintenance of political parties. The focus is on the case of two parties, Batasuna and Sortu, the first banished due to its connections with the terrorist group ETA, and the second the target of accusations of merely being a successor of the first. The article also examines the decisions of the Spanish Supreme Court that banished parties connected to the Basque Nation and the judgment of the legality of the Sortu party.
\end{abstract}

Keywords: Spain, political parties, Basque Nation

\title{
Resumo
}

Este artigo fará uma análise dos limites constitucionais e legais na Espanha para a criação e manutenção de partidos políticos. O foco será o caso de dois partidos: Batasuna e Sortu. $\mathrm{O}$ primeiro, banido por conta de suas conexóes com o grupo terrorista ETA e o segundo, alvo de acusações de ser mero sucessor do primeiro. $\mathrm{O}$ artigo também examinará as decisões tomadas pela Corte Suprema Espanhola que levaram ao banimento de partidos ligados à Nação Basca e a legalidade do partido Sortu.

Palavras-chave: Espanha, Partidos Políticos, Nação Basca 


\section{The limits on political parties in the Spanish Constitution of 1978 .}

Article 6 of the Spanish Constitution (SpCon) of 1978 sets out two limits on the actions of political parties. Firstly, they must observe the Constitution and the law during their founding and while carrying out their activities, and secondly, their internal structure and operation must be democratic. Therefore, political parties in Spain are free to carry out their activity provided they observe the Constitution and the law, which means a party may ideologically be committed to a complete political transformation. No control may be exercised over the party's aims and objectives (ideology) as the Constitution makes no mention of having to align party aims with any provisions in the Constitution. Furthermore, and this is vitally important, the Constitution allows amending any part of it and even the entire document (Articles 167 and 168 of the SpCon), which means proposals for constitutional reform aiming to establish a new constitutional system radically divergent from the current system are admissible. Therefore, if the Constitution allows the Spanish Parliament and the electorate (in accordance with the procedure set out in Article 168 of the SpCon) to pass a constitution that is ideologically opposed to the Constitution of 1978 , the founding and the activity of political parties can never be restricted on ideological grounds ${ }^{1}$. Otherwise, the existence of a Marxist-Leninist party could be prohibited while the Spanish Parliament could itself instate a regime of this nature, which would be inadmissible according to legal logic. In terms of the aims of political parties, Article 6 of the SpCon seeks to establish a general obligation to comply with the Spanish legal system rather than a duty to adhere to the ideological postulates underlying the Constitution in the German sense of a militant democracy (Spanish Constitutional Court-CC Judgment 164/1983 of 16 December on the observance of the Constitution by members of parliament; CC Judgement 48/2003 of 12 March, Conclusion of Law -Fundamento Jurídico-7; Spanish Supreme Court-SC Judgement of 27 March 2003, pp. 62-64). However, the Constitution does not allow the amendment of its legal framework by means contrary to the Constitution itself, i.e., where the activities of a party violate the Constitution in pursuing a political ideology violating provisions therein ${ }^{2}$.

Article 6 of the Constitution was not implemented into legislation until 2002, although this was not a case of a legal void as a statute, Spanish Law 54/1978 of 4 December on Political Parties, had been in force from just a few days prior to the Constitution that provided for the dissolution of a party where its activities "were contrary to democratic principles" (Article 5.2), although, without really specifying how these activities would be antidemocratic, it lacked the minimum requirements of certainty and security.

\footnotetext{
1. R. Blanco Valdés, “A proposito della «illegalizzazione» di Batasuna”, 4 Quaderni costituzionali (2002), p. 767.

2. CC Judgment $48 / 2003$ of 12 March (Conclusion of Law 7).
} 


\section{The situation under Spanish Law 54/1978 on Political Parties (1978-2002).}

Law 54/1978 was not, however, applied to prohibit political parties owing to the rejection in Spain at that time of the previous situation under the Franco dictatorship in which all political parties except the organisation that supported the regime, Movimiento Nacional (National Movement) ${ }^{3}$, were prohibited. Specifically regarding Herri Batasuna (HB; Popular Unity) ${ }^{4}$, the focus of this paper, from 1978 it was an electoral coalition of various political parties acting in collaboration with the ETA military-terrorist group. Years later, it opted to form a political party and submitted its application to the Registry of Political Parties. The Spanish Ministry of the Interior rejected its application, and this decision was appealed in the courts, which found in favour of the party founders ${ }^{5}$. The SC's Final Judgment of 31 May 1986 found that HB's statutes

do not amount to prima facie evidence of the offence referred to under the legal principle whose violation forms the basis of the complaint, which could be grounds for preventing the registration of the proposed Political Party. This statement is made without prejudice to, as can occur with any registered association, that said party might, once registered, not carrying out its activities within the limits of the legislation and acting beyond them by inadequately or illegally pursuing the principles and statements set out in the manifestation of its will in its statutes that enabled its registration and setting out to obtain objectives contrary to the SpCon or law or having of an undemocratic structure or operation, all of which is unlawful for being in breach of Article 6 of the SpCon, which evidently could lead to the dissolution of the political entity as set out abstractly under Article 22.4 of the SpCon and specifically in Article $5.2 \mathrm{a}$ ) and b) of Law 54/1978.

Subsequent to its definitive legalisation in 1986, Herri Batasuna acted as the political wing of the ETA terrorist group, with some members being in both organisations, making use of coercion against members of other parties and unconditionally supporting the murders, kidnapping and destruction perpetrated by $E^{2} A^{6}$. In the mid-90s, HB came up with its "socialisation of suffering" policy in which the "suffering" is that of the terrorists when arrested or imprisoned and of their families on having to travel to the prisons. According to HB, said policy is maintained by all sectors of society it believes are not aiming to resolve this situation, i.e., members of non-nationalist parties, judges, journalists, professors, etc., who it proceeds to harass, threaten, kidnap or murder.

\footnotetext{
3. http://es.wikipedia.org/wiki/Movimiento_Nacional

4. http://es.wikipedia.org/wiki/Herri_Batasuna

5. Judgments of the Madrid Court of First Instance of 29 September 1984 and the Madrid Regional Court of 28 October 1985.
}

6. See SC Judgment of 27 March 2003, pp. 72-127, for a detailed account of HB's collaboration with ETA. 


\section{Spanish Organic Law 6/2002 on Political Parties.}

Under the threat of being banned, HB decided in 1998 to act under the coverage of an electoral coalition formed by other like-minded, minority parties controlled by $\mathrm{HB}$ under the name of Euskal Herritarrok (EH; Basque Citizens), and in $2001 \mathrm{HB}$ re-formed as Batasuna (Unity). At this time, the governing PP party and the main party in opposition, the PSOE, agree to repeal Law 54/1978 and pass Organic Law 6/2002 of 27 June on Political Parties (OLPP) to prevent the continuation of a political movement in the Basque Country that, under various party denominations (HB, EH and Batasuna), had been, since 1978, the accomplice required by the ETA terrorist group to intimidate social and political opponents. The effective application since 2003 of the OLPP has meant the exclusion from the democratic political playing field of political parties clearly linked to the ETA terrorist organisation that had managed to take advantage of all the slightest opportunities provided by a democratic state to terrorise a large proportion of the Basque population, to intimidate elected representatives of "constitutionalist" parties and effectively support terrorist activity, making the effective exercising of fundamental rights and having a political contest under conditions of equality impossible.

Under Article 9.1 of the OLPP, party activities

shall be undertaken observing constitutional values expressed in democratic principles and human rights. Parties shall carry out the functions constitutionally and democratically granted to them while demonstrating complete observance of the principle of pluralism.

The second point of this article (9.2) outlaws any activity that violates democratic principles but specifically states that this will occur "particularly when it aims to reduce or destroy freedoms or make impossible or eliminate the democracy system." In other words, the target of the conditions of illegality foreseen by the statute are parties aiming to prevent the exercising of constitutional rights by other citizens, which leads to the de facto disappearance of democracy. Based on this first definition of the antidemocratic activities of a party, the statute sets out in Article 9.2 that this must take the form of certain repeated and serious conduct that amounts to violating fundamental rights; inciting, encouraging or legitimising violence as a political means; or providing political support to terrorism. Furthermore, entering into specific circumstances not covered in Law 54/1978 and with the clear intention to cover all possible activities that Batasuna had been known to engage in until that time, Article 9.3 of the OLPP lists in what cases the circumstances set out in the previous section exist. 


\section{The banning of $\mathrm{HB}, \mathrm{EH}$ and Batasuna (2003-2009)}

The first practical application ${ }^{7}$ of the OLPP ${ }^{8}$ occurs in the proceedings giving rise to the SC's Judgment of 27 March $2003^{9}$ outlawing the political parties HB, EH and Batasuna and ordering their dissolution.

The SC's judgment devotes over 50 pages $^{10}$ to examining the evidence for the facts it finds to be proven with respect to the founding and succession of the three parties, detailing ETA's participation in said parties ${ }^{11}$.

The persistence of the activity in support of ETA undertaken by Batasuna subsequent to 29 June 2002 leads the SC to focus on prohibiting acting as a political wing for terrorism (Article 9.2.c of the OLPP), given that Batasuna's conduct would be "a conscious and repeated political activity complementary to terrorism via politics", because, in accordance with European Court of Human Rights (ECHR) caselaw (Judgment of 13 February 2003), it is insufficient for party leaders to refrain from calling for the use of violence; they must also distance themselves from party members that support the potential use of violence ${ }^{12}$.

In this process of banning $\mathrm{HB}, \mathrm{EH}$ and Batasuna, particularly noteworthy is the application of the "lifting the veil" technique to demonstrate that ETA is always present behind the three parties in question as there is a particular identity in terms of the people in leading and representative roles, a succession among the parliamentary and municipal groups of the three parties, a succession in the use of offices and premises, strategies and action programmes substantially identifiable as being designed by ETA, and the use of anagrams linked to the activity of terrorist organisations. ${ }^{13}$

Finally, the SC outlaws the HB, EH and Batasuna parties (Article 11.7 of the OLPP) in finding all the "strict criteria that both international treaties and national, ordinary and constitutional caselaw and the ECHR's caselaw require for determining the restriction of a fundamental right"14, as provided for by law and required for a democratic society given

7. Batasuna had been previously criminally suspended by an order issued by First-Instance Cntral Criminal Court number 5 (Judge Garzón) in applying Article 129 of the Spanish Criminal Code. This criminal proceedings was still under way at the time this paper was being written. For reasons of brevity, I refer to my work on this subject: E. Vírgala Foruria,"El recorrido jurisprudencial de la suspensión y disolución de Batasuna: agosto de 2002 a mayo de 2007”, 81 Revista Española de Derecho Constitucional (2007), pp. 243-305.

8. With regards to the OLPP, see E. Vírgala Foruria, "Los límites constitucionales a los partidos políticos en la LO 6/2002", J. A. Montilla Martos (ed.), La probibición de partidos politicos, Almería, Universidad de Almería (2004), pp. 45-98.

9. See E. Vírgala Foruria,"El recorrido jurisprudencial de la suspensión y disolución de Batasuna: agosto de 2002 a mayo de 2007", 81 Revista Española de Derecho Constitucional (2007), pp. 243-305, for a more detailed analysis of this judgment.

10. SC Judgment of 27 March 2003, pp. 72-127.

11. SC Judgment of 27 March 2003, pp. 25-41.

12. SC Judgment of 27 March 2003, pp. 159-160.

13. SC Judgment of 27 March 2003, pp. 242-245.

14. SC Judgment of 27 March 2003, pp. 248-249. 
the fully demonstrated fact that the defendant parties are manifestations of the cited 'tactical separation' strategy employed by terrorism on frequent occasions, and, as a result of which, the frequent calls - made in internal documents or public acts- to use violence ('armed struggle'), mean that the defence of the fundamental rights of others, a vital component of democracy, requires the aforementioned ruling of prohibition and dissolution", resulting in the restriction of a fundamental right that is sufficiently justified in pursuance of the benefit of "an immediate protection of democracy and the fundamental rights (including even the most basic and evident) of others, meaning that, in this case, it is evident that all the conditions are present to warrant and make completely legitimate the legal restriction of the founding and forming part of political parties"15.

Appealed on grounds of violation of constitutional rights before the CC, the SC Judgment of 27 March 2004 is confirmed by CC Judgment 5/2004 (Batasuna) and 6/2004 (Herri Batasuna) of 16 January. The $\mathrm{CC}$ confirms the legality of the dissolution of the three parties and establishes a criterion, which would be determinant in subsequent judicial proceedings, on the effects the condemning of terrorism has on the banning of a political party. In these judgements, the CC examines if not condemning terrorism can be grounds for banning a party under the OLPP. On this point, the CC says that "not condemning terrorist actions is also a tacit or implicit manifestation of a particular posture towards terror" and that in the context of 30 years of terrorism

a party not condemning a terrorist attack, as an obvious ploy for standing out in contrast to the condemnation made by other parties, takes on an evident weight made significant by accumulation as it is imbued by the added meaning it receives owing to the direction taken in the trajectory observed with regard to this aspect by a party that has typically afforded a generous understanding towards terrorism that, at the very least, portrays it as an inevitable reaction to an initial and unjust aggression on behalf of the state affected by the terrorism.

Although it is true that the $\mathrm{CC}$ immediately goes on to say that

it has also been proven in the original proceedings that the non-condemnation is added to the various, serious and repeated, acts and conduct from which a commitment to terror and against the coexistence organised in a democratic state can be reasonably deduced. Said unwillingness to condemn is accompanied by ambiguous statements that put the state and terrorism at the same level. On this premise, no qualitative distinction is made between the public authorities, which legitimately monopolise the forces of the state - and a terrorist group - whose violence amounts only to criminal acts, by which it aims to reduce or displace this group's responsibility. The legal consequence of the foregoing must be, as it has been, the withdrawal of the status of party from any political organisation found to be outside the scope of the institution provided for in Article 6 of the SpCon ${ }^{16}$.

15. SC Judgment of 27 March 2003, p. 250.

16. CC Judgment 5/2004, of 16 January (Conclusion of Law 18). 
Six years after Herri Batasuna and Batasuna were banned by the SC, the ECHR validated this prohibition ${ }^{17}$ and, moreover, unanimously and categorically in its Fifth Chamber ${ }^{18}$. From a legal point of view, this judgment represents a definitive recognition of the OLPP and its judicial application, which, in turn, amounts to a strengthening of the Spanish democracy and of the adequate functioning of its legal and judicial mechanisms in the fight against terrorism and its political arms.

The ECHR examines the case of Herri Batasuna and Batasuna and does not hesitate to make a series of affirmations that fully support the original findings of the Spanish courts.

The ECHR analyses whether the dissolution of HB and Batasuna met a "pressing social need" and whether in this particular case it was "proportionate to the legitimate aims pursued"19. The Strasbourg Court considers that the SC proved in its Judgment of 2003 that HB, EH and Batasuna engaged in a range of conduct that permitted reaching the conclusion that these parties were, and this is very significant, "instruments of ETA's terrorist strategy", having encouraged a climate of social confrontation between these parties and others present in the Basque Country to the extent of causing violent acts that disrupted the public order and engaged in "conduct having implicitly supported ETA's terrorist activities". Such conduct bears "a strong resemblance to explicit support for violence and the commendation of people seemingly linked to terrorism"20.

With regard to the non-condemnation of terrorism, the Court states that this is not the only element to be taken into account to rule for dissolution but goes further in stating:

In any event, the Court points out that merely because the dissolution was partly based on failure to condemn did not make it incompatible with the Convention. A politician's conduct usually includes not only his or her actions or speeches but also, in some circumstances, omissions or a lack of response, which can constitute acts indicating that politician's stance and be just as telling as any overtly supportive action ${ }^{21}$.

In short, the ECHR concludes that the banning of Batasuna is "a pressing social need" as it "sees no reason to depart from the reasoning of the Supreme Court concluding that there was a link between the applicant parties and ETA", "that link may objectively be considered to constitute a threat to democracy" and "the actions and speeches imputable to the applicant political parties, taken together, give a clear picture of a model of society conceived and advocated by them, which is incompatible with the concept of a democratic society ${ }^{\prime 2}$ ". Said incompatibility entails "a considerable threat to Spanish democracy", which makes the banning "proportionate to the legitimate aim pursued, within the meaning of Article 11.2"23

17. Hereinafter, ECHR Judgment Herri Batasuna and Batasuna of 30 June 2009.

18. Judgment made final on 6 November 2009 on the Court not admitting the appeal presented by the banned parties for the case to be heard in the Grand Chamber.

19. ECHR Judgment Herri Batasuna and Batasuna of 30 June 2009, point 84.

20. ECHR Judgment Herri Batasuna and Batasuna of 30 June 2009, points 85 and 86.

21. ECHR Judgment Herri Batasuna and Batasuna of 30 June 2009, point 88.

22. ECHR Judgment Herri Batasuna and Batasuna of 30 June 2009, points 89 and 91.

23. ECHR Judgment Herri Batasuna and Batasuna of 30 June 2009, point 93. 


\section{The banning of ANV (2008-2013)}

Five years after the banning of Batasuna, a proceedings was initiated to ban the Accion $\mathrm{Na}$ cionalista Vasca (ANV) (Basque Nationalist Action) party. The SC, in its Judgment of 22 September 2008, reminds that, on this occasion as part of the banning of ANV's list of candidates in $2007^{24}$, there was evidence of an accord of action between Batasuna and ANV, but it is after these elections when such evidence is confirmed and "the intention of ANV to publicly present itself to its electorate as a party in full harmony and collaboration with the banned BATASUNA" becomes manifest ${ }^{25}$. Thus, it bans ANV.

In the appeal filed on grounds of violation of constitutional rights, the CC (31/2009 Judgment of 21 January) upholds that the SC

has concluded, with sufficient legal reason, that the facts and circumstances meticulously examined in Conclusions of Law 5 and 7 of the judgment fully integrate the provisions of Article 9.2 c) with regard to Article 9.3 b), both of the OLPP ${ }^{26}$.

The CC found that the SC

had not banned the appellant party only because of its ideological coincidence with ETA, but for having found, with sufficient legal reason, that the campaign of intimidation directed by numerous election candidates following the 2007 elections and the boycott organised in accord with BATASUNA, and always following ETA's orders, against the Constitution by certain city local governments, was perfectly compatible with the circumstances set out in Article 9.3 b) of the OLPP"27

and owing to the

existence of a financial relationship between one $[\mathrm{ANV}]$ and the other [ETA-Batasu$n a]$, in which case, the continued link between the now dissolved party and what it was at the time to be used as ETA saw fit has been demonstrated ${ }^{28}$.

The CC also deems correct the SC's assessment of "the stance maintained by EAE/ANV towards certain terrorist attacks, in particular, and with regard to ETA's activity"29. Thus, it finds, in accordance with its previous caselaw (CC Judgment 68/2005 of 31 March), stating

24. See E. Vírgala Foruria,"El recorrido jurisprudencial de la suspensión y disolución de Batasuna: agosto de 2002 a mayo de 2007", 81 Revista Española de Derecho Constitucional (2007), pp. 243-305, for more on this banning.

25. SC ANV Judgment of 22 September 2008, Conclusion of Law 7.

26. CC Judgment $31 / 2009$ of 21 January 2009 (Conclusion of Law 6).

27. CC Judgment 31/2009 of 21 January 2009 (Conclusion of Law 7).

28. CC Judgment 31/2009 of 21 January 2009 (Conclusion of Law 8).

29. CC Judgment 31/2009 of 21 January 2009 (Conclusion of Law 10). 
there can be, therefore, no doubt that the stance the Supreme Court attributes to the appellant taken towards certain terrorist attacks was based on facts, omissions and conduct that, duly demonstrated in the proceedings, led the Special Chamber of the Article 61 Ley Orgánica del Poder Judicial (Spanish Organic Law on the Judiciary), with sufficient legal reason, to the conclusion that it could not be considered an explicit and unconditional condemnation of the terrorism. Such a condemnation of terrorism, in the context of a process for the banning of a party considered to be in collusion with ETA, would be counter-evidence sufficient to counteract other elements of reasonable evidence for basing the court's assessment that a political party acts and is used as a mere instrument for terrorism ${ }^{30}$.

The CC Judgment 31/2009 of January 2009 was appealed before the ECHR, as occurred with the banning of Herri Batasuna and Batasuna, and the Third Chamber unanimously handed down its judgment on 15 January 2013 on the ANV vs Spain case ${ }^{31}$. The ECHR considers that the banning complies with all the requirements set out in caselaw: provision in law ${ }^{32}$; legitimate aim, especially maintaining public order, defending the legal system and the protecting the rights and freedoms of others ${ }^{33}$; and the need for a democratic society and the proportionality of the measure, restating, regarding this aspect, its 2009 judgment on Herri Batasuna and Batasuna. The ECHR considers that the party statutes must be taken into account, but, as the banning derives from the confusion of ANV with Batasuna and ETA, it sets out to assess "in particular the specific activities and possible connections of the appellant political party with the dissolved Batasuna party"34, which would amount to conduct revealing an implicit support of ETA's terrorist activities ${ }^{35}$, conducive to a climate of social confrontation ${ }^{36}$. The ECHR also takes into account the financial relationships between ANV and Batasuna $/ \mathrm{ETA}^{37}$. All of which means that, when considered jointly, these acts must be seen as part

of a strategy adopted by the claimant party to implement a political project that, in essence, is contrary to the democratic principles enshrined in the Constitution of 1978 (Herri Batasuna and Batasuna, cited, point 87) and which correspond to the condition for dissolution set out in Article 9.2 of the OLPP combined with paragraph 3 of said article with regard to the claimant party having subjected elected representatives to a

\footnotetext{
30. CC Judgment 31/2009 of 21 January 2009 (Conclusion of Law 11).

31. ECHR ANV Judgment of 15 January 2013.

32. ECHR ANV Judgment of 15 January 2013, points 50-51.

33. ECHR ANV Judgment of 15 January 2013, point 54.

34. ECHR ANV Judgment of 15 January 2013, point 69.

35. ECHR ANV Judgment of 15 January 2013, point 71.

36. ECHR ANV Judgment of 15 January 2013, point 72.

37. ECHR ANV Judgment of 15 January 2013, point 73.
}

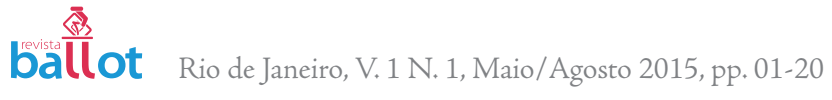


climate of intimidation to prevent them from freely expressing themselves and participating in the city local governments they had been democratically elected to ${ }^{138}$.

With regard to the absence of any condemnation of terrorism, the Strasbourg Court finds that, as it did in its judgment of 2009, that such grounds for dissolution are not contrary to the European Convention on Human Rights, as it is possible, in some cases, to consider the silence of not issuing of any response as equivalent to a statement of support ${ }^{39}$.

In short, ANV's actions and speeches provide a clear picture of a model of society in contradiction with the concept of a "democratic society", which poses a serious threat for Spanish democracy, meaning that its dissolution is a "pressing social need" as occurred previously with Herri Batasuna and Batasuna ${ }^{40}$, with the sanction proportionate to the legitimate aim pursued under Article 11.2 of the European Convention on Human Rights ${ }^{41}$.

\section{The banning of PCTV (2008)}

The proceedings for banning of the Partido Comunista de las Tierras Vascas party (PCTV) (Communist Party of the Basque Homelands) occurs at the same time as ANV's and comes into force with the Judgment of 22 September $2008^{42}$.

The SC finds that the conduct of the PCTV coincides with that set out in Article 9.2 c) of the OLPP as

a political complement and support for the action of terrorist organisations carried out through the explicit support of a political party banned for being part of the terrorist tactics of the ETA organisation. The political support of terrorism described is evident through the defendant party permanently, and therefore cumulatively, (1) handing over the rights and prerogatives the legal system grants to political parties (Article 9.3 e) of Organic Law 6/2002), and (2) having a large number of members who are also members in entities (in the case of Batasuna) linked to a terrorist group and collaborate with these entities (Article $9.3 \mathrm{f}$ ) of Organic Law 6/2002) ${ }^{43}$.

As a result, the SC bans PCTV.

38. ECHR ANV Judgment of 15 January 2013, point 74.

39. ECHR ANV Judgment of 15 January 2013, point 76.

40. ECHR ANV Judgment of 15 January 2013, point 79.

41. ECHR ANV Judgment of 15 January 2013, point 81.

42. See E. Vírgala Foruria, “Los efectos jurídicos de la ilegalización de partidos políticos(2003-2008)”, 28

Cuadernos de Alzate (2008), pp. 65-87, for a more detailed analysis of this judgment.

43. SC PCTV Judgment of 22 September 2008, Conclusion of Law 13. 


\section{The legalising of Sortu (2011-2012)}

In 2011, the OLPP could not be applied in the same way after the ETA terrorist group had decided to permanently abandon the use of violence ${ }^{44}$ and, in particular, after the political movement that had collaborated with ETA stopped acting as a political wing, rejecting violence as an instrument of political action and accepting the diversity of ideological viewpoints.

From 2011, the key question was whether what the banned Batasuna represented (personally and ideologically) could be "recycled", given certain conditions, into a new party that was not a continuation or succession of the original entity in the terms of Article 12.3 of the OLPP. Provided, of course, that the leadership of the original Batasuna expressly distanced itself from the previous activities that violated fundamental freedoms and rights (Article 9.2.a of the OLPP). This declaration would have to be an explicit break from ETA's terrorist violence as this was the main reason for the party being declared illegal. In Judgment 99/2004, the CC stated that,

if it indeed accepts the vote and free debate as the only legitimate instruments, making a clear declaration of separation, rejection and condemnation of everything a criminal organisation and its political instruments represent; and it does so out of respect, firstly, for those whose vote it wants to make part of, under its representation, the will of the public authorities. This would have to be enough to undo the probative value of evidence that, against such an indisputable declaration, would be hard pressed to prove a reality to the contrary ${ }^{45}$.

In the six years following its banning (2003-2009), Batasuna's attitude remained unchanged. It collaborated with the terrorist group and protected ETA's violence, which meant that its successive reincarnations were declared illegal, on justified grounds, by the SC: ANV and PCTV in 2008. However, after 2011, the circumstances are radically different. The failure in 2006 of the negotiations between Spain and ETA, and the widely held perception in Basque society of ETA's fault for this failure, sees the Izquierda Abertzale (Patriotically Left) ${ }^{46}$, represented by Batasuna until this time, rethink its strategy, which contributes to, in no small measure, the ECHR's Judgment of June $2009^{47}$. From this point on, the debates are characterised by disagreements between ETA and significant factions of Batasuna. In the end, the option for exclusive political participation and abandoning what is referred to as the political-

\footnotetext{
44. ETA declares a "ceasefire" on 5 September 2010 that on 10 January 2011 becomes "permanent, general and verifiable by international observers" and, finally, results in "the permanent end of its armed struggle" on 20 October 2011. Since then, ETA has committed no further acts.

45. CC Judgment 99/2004 of 27 January, Conclusion of Law 19.

46. This name is used to refer to the movement that, linked to ETA, includes parties and social movements that have supported the terrorist violence.

47. See E. Vírgala Foruria,"El TEDH avala la ilegalización de Batasuna (aspectos positivos y algunos pocos negativos de su jurisprudencia)", 13 Revista de Derecho Constitucional Europeo (2010), pp. 415-436, for details on the ECHR Judgment of 30 June 2009.
} 
-military strategy wins out ${ }^{48}$. Fruit of which are the statements of leaders of the old Batasuna made from mid-2009 that culminate with the act in Bilbao in January 2011 in which a language unheard of from this faction since the founding in April 1978 of Herri Batasuna is used to declare a complete breakaway from previous political activity.

A decisive step in this evolution was the creation on 30 January 2011 of a new party, Sortu (Create), which includes in its party statutes the aforementioned type of language and some revealing provisions, such as those about contributing to "the final and total disappearance of any type of violence and terrorism, in particular, that of the ETA organisation" (Preliminary Chapter) and announcing its rejection of violence "in any form regardless of its origin or nature; rejection that, openly and unconditionally, includes the ETA organisation as perpetrator of any conduct that violates the fundamental rights and freedoms of people" (Article 3.B). These statutes are submitted to the Registry of Political Parties on 10 February. The Spanish State Legal Service and the Public Prosecutor's Office contest the registration and request that the SC rule that Sortu is Batasuna's successor and that it should not be legalised. In its Order of 30 March 2011 on the registration of Sortu (SC Order on Sortu) ${ }^{49}$, the SC rejects the registration of the party.

The first conclusion we can draw from the SC Sortu Order is that the court opted for stopping Izquierda Abertzale becoming legal in Spain, even if this organisation emphatically rejects ETA's use of terrorism. The Court states this on page 208 of its Sortu order: "the only and inevitable legally available end for a banned party is its dissolution and dismantling; not its legal and political 'resurrection' under the pretext of a change in its methods or means of action."

This is a very disappointing conclusion as it obstructs the reintegration of a significant part of society into politics that, regardless of any moral judgement that can be made of its actions over the last 35 years, has decided, albeit probably owing to utilitarian reasons, to break its ties with terrorism. If this socio-political movement opts for working politically without supporting coercive means, the democratic state's only course is to accept this situation and legalise a political option that part of the Basque society identifies with. A party that might represent between 15 and $20 \%$ of the electorate that has decided to act using political and legal means without collaborating with ETA or supporting its actions cannot remain outlawed.

The Spanish Constitution is embedded by a whole series of principles and provisions that urge the legalising of all parties that have accepted to act within the constitutional framework. The "advanced democratic society" stated in the Preamble cannot be constructed with the presumption, apparently juris et de jure, that an important socio-political group can never correct its behaviour and, therefore, must remain illegal. If "political pluralism" is a supreme value in our legal system (Article 1.1) and the parties are its expression (Article 6.1), only conclusive evidence that a party proposes to end such pluralism can lead to its expulsion from the political field of play. Likewise, only the constitutional limits set out in Article 22 of the SpCon and the actions contrary to the Constitution, referred to in Article 6 of the SpCon, can put a question mark over the existence of a political party, but never its ideology, regardless of how

48. This does not mean we can say with certainty that all ETA members are in agreement with this result, at least at this time.

49. See E. Vírgala Foruria,"El Auto sobre Sortu: una visión estática (y poco constitucional) de la Izquierda Abertzale”, 20 El Cronista del Estado social y democrático de derecho (2011), pp. 18-25, for a more detailed analysis of this Order. 
far towards self-determination and independence it leans. All of which must be based on an expansive and never a restrictive interpretation of the fundamental rights underlying Article 10.1 of the SpCon, which the CC has always applied ${ }^{50}$.

In its Batasuna Judgment of 30 June 2009, the European Court of Human Rights itself stresses that elections should be contested by "a plurality of political parties representing the different shades of opinion to be found within a country's population" and that restrictions on the activity of a party must be interpreted restrictively ${ }^{51}$.

An ETA document from the second half of 2009 ("Democratic Process") is the key for the SC, from which it interprets that ETA designed the whole process leading to the application for the registration of Sortu in February 2011. The problem is that the lead up in this document is not a faithful reflection of the reality, and although it is finally said to be direct proof of ETA's participation in the creation of Sortu, these are actually only conjectures formed in contrast to the reality and seem to even overlook important facts such as the setback that was "Mugarri's", of ETA, speech defending the continuation of terrorism and the Izquierda Abertzale debate of October 2009.

Here, as mentioned above, the impossibility for Izquierda Abertzale to be legalised in Spain while ETA exists is evident, even though it categorically rejects the terrorist group's activities. The view of what the Izquierda Abertzale socio-political movement in the Basque country is and what it represents is completely static - setting what it once was in stone; there is no dynamic or evolutionary view of this social phenomenon.

In the case of Sortu, a detailed assessment of its party statutes and the statements of its founders regarding the rejection of ETA's terrorism should have been vital. Significantly, the act in Bilbao on January 2011 can be seen as a declaration to completely break away from the political action that had been undertaken until relatively recently. Izquierda Abertzale's will is confirmed, set down subsequently in writing in Sortu's statutes, to contribute to "the final and total disappearance of any type of violence and terrorism, in particular, that of the ETA organisation" (Preliminary Chapter) and announce its rejection of violence "in any form regardless of its origin or nature; rejection that, openly and unconditionally, includes the ETA organisation as perpetrator of any conduct that violates the fundamental rights and freedoms of people" (Article 3.B). This declaration, along with previous ones, emphasises the current absence of collaboration with ETA terrorism, which was the main reason for banning Batasuna. In this sense, the announced sanction of expulsion for any future member that carries out "any conduct set out in Article 9 of Organic Law 6/2002 on Political Parties" (Article 11.4) is vital.

Does this constitute the determinant element (against collaboration with terrorism) to which the $\mathrm{CC}$ and the SC referred in their decisions over recent years? I believe it clearly does. The SC required the prior undertaking of "rejecting all collusion with anyone employing violent, and, therefore, essentially antidemocratic, means and, as a result, categorically rejecting the terrorist activities for which the political party was banned for abetting". Thus, on the people who formed part of banned parties "there is greater onus, to dispel all and any doubt,

\footnotetext{
50. For instance, CC Judgment 1/1989 of 16 January.

51. For example, ECHR Judgments on the United Communist Party of Turkey of 30 January 1998, points 44 and 46, on the Turkish Socialist Party of 25 May 1998, point 50, and on the Turkish Democracy and Freedom Party of 8 December 1999, point 44.
} 
for an unequivocal rejection of the terrorist violence that led to the banning" ${ }^{\prime \prime 2}$. The CC considered that an "unequivocal condemnation" of terrorism was required ${ }^{53}$. However, despite how categorical the rejection of terrorism and, in particular, of ETA, is, the SC finds this gesture to be mere rhetoric.

In the appeal filed on grounds of violation of constitutional rights against the SC Sortu Order, the CC handed down Judgment 138/2012 of 20 June in which it upholds Sortu's appeal and recognises this political party's right to become officially registered. CC Judgment $138 / 2012$ heads in the same direction taken in 2009 with the appeal on grounds of violation of constitutional rights upheld for Iniciativa Internacionalista ${ }^{54}$ and in 2011 for Bildu ${ }^{55}$. It is not constitutionally possible in Spain to exclude from politics a party that categorically rejects the use of terrorism.

One of the key differences compared to previous banning proceedings is that the CC is, for the first time, faced with an application to register a new party whose activity amounted to little more than submission for registration and founding before Notary Public owing to the fact that it had not been registered by the Ministry of the Interior.

In the case of Sortu in 2011, having no history of activity when the State Legal Service and the Public Prosecutor's Office filed its initial claims, the aforementioned doctrine established in the 90s by the ECHR regarding the difficulties of determining the legality of a recently founded party without practically any activity is especially relevant. The Strasbourg Court considers that the statutes and political programme must be analysed alongside the actions and statements of the new party's leaders. The ECHR considers that

there can be no justification for hindering a political group solely because it seeks to debate in public the situation of part of the State's population and to take part in the nation's politics in order to find, according to democratic rules, solutions capable of satisfying everyone concerned ${ }^{56}$,

52. SC Order of 22 May 2007, Conclusion of Law 10.

53. CC Judgment 68/2005 of 31 March, Conclusion of Law 16.

54. Election candidate list of various parties for the European elections of 2009. The election list was prohibited by the SC in its Order of 16 May 2009 on deciding that it was linked to the banned Batasuna, but the CC quashed this decision and allowed its submission in CC Judgment 126/2009 of 21 May. See E. Vírgala Foruria,"La admisión de Iniciativa Internacionalista a las elecciones europeas de 2009: El TC corrige acertadamente la decisión del TS, 87 Revista Española de Derecho Constitucional (2009), pp. 315-336, for more on this case.

55. Election candidate list of various parties for the municipal elections of 2011. The election list was prohibited by the SC in its Judgment of 1 May 2011 on deciding that it was linked to the banned Batasuna, but the CC quashed this decision and allowed its submission in CC Judgment 62/2011 of 5 May. See E. Vírgala Foruria, "Las sentencias del TS y del TC de mayo de 2011 sobre Bildu y las Agrupaciones electorales", 93 Revista Española de Derecho Constitucional (2011), pp. 307-326, for more on this case.

56. ECHR Judgment on the United Communist Party of Turkey of 30 January 1998, points 57; in similar terms, ECHR Judgment on the Turkish Democracy and Freedom Party of 8 December 1999, point 41. 
for which a comparison of its programme and its activities is impossible in the case of the United Communist Party of Turkey as it was dissolved immediately following its creation ${ }^{57}$.

As the founding of a political party is exclusively a statement of the will of its founders, its activity can only be judged from when it becomes active as to whether it respects the Constitution and the law as set out in Article 6 of the SpCon, clearly in accordance with the aforementioned ECHR caselaw.

Given the foregoing, the CC examines the two elements it possesses to assess whether Sortu is a mere successor of Batasuna: its statutes and the activity planned by the banned party for the new one.

With regard to the first element, the party statutes ${ }^{58}$, the CC examines the various sections. On this point, there is little doubt over the legitimacy of Sortu's statutes in terms of the OLPP as they were very carefully drafted to meet the conditions set by the CC in its caselaw. The document states the intention to contribute to "the final and total disappearance of any type of violence and terrorism, in particular, that of the ETA organisation" (Preliminary Chapter) and announces the rejection of violence "in any form regardless of its origin or nature; rejection that, openly and unconditionally, includes the ETA organisation as perpetrator of any conduct that violates the fundamental rights and freedoms of people" (Article 3.B). In this sense, the sanction of expulsion for any future member that carries out "any of the conduct set out in Article 9 of Organic Law 6/2002 on Political Parties" (Article 11.4) is vital.

As there is no evidence contrary to the rejection of terrorism, either in the party statutes or the statements made by Sortu's leaders, the CC can only confirm that the condemnation of terrorism

cannot be subject to the - legally unresolvable - dilemma of assessing the extent of the party's sincerity, although it can be conditioned by the objective identification of the real intention of the statements in which counter-evidence would consist of an intention that can only be discovered as evidence to the contrary (and, therefore, hidden) based on observable facts attributable to the party intending to exercise its fundamental right' (CC Judgment 62/2011 of 5 May, Conclusion of law 12).

In this case, it cannot be ignored that the SORTU political party emphatically sets out in its statutes an action programme based exclusively on political and democratic means, its breakaway from the structures and political organisations outlawed and dissolved by court ruling owing to collusion with the ETA terrorist group, and its rejection of violence as a political instrument or means to achieve its political aims, including those of said terrorist group. In an equally as firm and categorical manner, the founders and leaders of the SORTU political party, in the act presenting said political organisation, declared their commitment to the use of exclusively pacific and democratic means for achieving political aims and rejected the use of violence, including that of the ETA terrorist organisation ${ }^{59}$.

57. ECHR Judgment on the United Communist Party of Turkey of 30 January 1998, point 58.

58. Sortu's statutes can be downloaded at http://www.gara.net/agiriak/20110209_Estatutos_Sortu.pdf (last access: 15 January 2014).

59. CC Judgment 138/2012 of 20 June, Conclusion of Law 10. 
As the statutes were drafted taking into account the OLPP and constitutional caselaw on said legislation, the CC makes specific mention that said statutes

make these provisions their own by including in Article $3 \mathrm{~B}$ the literal content of Article 9 of the OLPP, precept in which the legislator describes in detail the serious and repeated types of conduct that can lead to the banning of a political party, with said statutes including the provision that any member engaging in any such conduct is a very serious offence sanctioned by expulsion from the party. Attention must also be drawn to the requirement for being a candidate on any of the SORTU political party's electoral lists of adopting its underlying ideology and commitment to political action and the rejection of violence, including that of the ETA terrorist organisation, and the use of exclusively pacific and democratic means for achieving political aims. ${ }^{60}$

All of which constitutes counter-evidence sufficient that, in principle, counteracts or dilutes the probative value of other elements of proof from which it could be inferred that the new political party seeking registration in the Registry of Political Parties may want to continue or follow on with the activity of political parties legally banned and dissolved under Judgment 1/2003 of 27 March [Article 12.1.b) OLPP].

With regard to the acts of the new party's leaders, in all their statements they have repeatedly expressed their commitment to political means and the unconditional rejection of violence. In what can be seen as a dynamic vision of Izquierda Abertzale, the CC determines that the foregoing should not be disqualified by the presence at certain acts, such as Euskalduna in Bilbao, of former Batasuna leaders. What matters is the current opting for exclusively pacific means and the rejection of violence.

As there is no evidence corroborating the existence of the elements set out in Article 12.3 of the OLPP to establish the succession or continuation of a banned party, the CC concludes that

"it cannot be inferred that [ETA and Batasuna] have set up the SORTU political party for its ends or that this party has let itself be used by the terrorist organisation and the banned political party so as to constitutionally require, in this case, restricting its right of association ${ }^{61}$.

60. CC Judgment 138/2012 of 20 June, Conclusion of Law 10.

61. CC Judgment 138/2012 of 20 June, Conclusion of Law 13. 


\section{References}

\subsection{Books.}

Corcuera Atienza, J., Tajadura Tejada, J., Vírgala Foruria, E., La ilegalización de partidos en las democracias occidentales, Madrid, Dykinson (2008).

Vírgala Foruria, E., "Los límites constitucionales a los partidos políticos en la LO 6/2002", J. A. Montilla Martos (ed.), La probibición de partidos politicos, Almería, Universidad de Almería (2004), pp. 45-98.

\subsection{Articles.}

Blanco Valdés, R., "A proposito della «illegalizzazione» di Batasuna”, 4 Quaderni costituzionali (2002), pp. 749-769.

Vírgala Foruria, E., "El cerco judicial a los partidos con vínculos terroristas", 48 Jueces para la Democracia (2003), pp. .

Vírgala Foruria, E.,"El recorrido jurisprudencial de la suspensión y disolución de Batasuna: agosto de 2002 a mayo de 2007", 81 Revista Española de Derecho Constitucional (2007), pp. 243-305.

Vírgala Foruria, E.,"Los efectos jurídicos de la ilegalización de partidos políticos(2003-2008)", 28 Cuadernos de Alzate (2008), pp. 65-87.

Vírgala Foruria, E.,"La admisión de Iniciativa Internacionalista a las elecciones europeas de 2009: El TC corrige acertadamente la decisión del TS, 87 Revista Española de Derecho Constitucional (2009), pp. 315-336.

Vírgala Foruria, E., "El TEDH avala la ilegalización de Batasuna (aspectos positivos y algunos pocos negativos de su jurisprudencia)", 13 Revista de Derecho Constitucional Europeo (2010), pp. 415-436.

Vírgala Foruria, E.,"Las sentencias del TS y del TC de mayo de 2011 sobre Bildu y las Agrupaciones electorales", 93 Revista Española de Derecho Constitucional (2011), pp. 307-326.

Vírgala Foruria, E.,"El Auto sobre Sortu: una visión estática (y poco constitucional) de la Izquierda Abertzale", 20 El Cronista del Estado social y democrático de derecho (2011), pp. 18-25.

\subsection{Cases.}

CC (Spanish Constitutional Court) Judgment 1/1989 of 16 January

CC Judgement 48/2003 of 12 March

CC Judgement 5/2004, of 16 January 
CC Judgement 99/2004 of 27 January

CC Judgment 126/2009 of 21 May

CC Judgment 31/2009 of 21 January

CC Judgment 62/2011 of 5 May

CC Judgement 138/2012 of 20 June

ECHR (European Court of Human Rights) Judgment United Communist Party of Turkey of 30 January 1998

ECHR Judgment Turkish Socialist Party of 25 May 1998

ECHR Judgment Turkish Democracy and Freedom Party of 8 December 1999

ECHR Judgment Herri Batasuna and Batasuna of 30 June 2009

ECHR Judgment ANV of 15 January 2013

Madrid Court of First Instance Judgment of 29 September 1984

Madrid Regional Court Judgment of 28 October 1985.

SC (Spanish Supreme Court) Judgment of 27 March 2003

SC Order of 22 May 2007

SC Judgment of 22 September 2008

SC Order of 16 May 2009

SC Judgment of 1 May 2011 
Recebido em: 10/03/2015

Aceito em: 13/04/2015

\section{Como citar}

FORURIA, Eduardo Vírgala. The banning of political parties in Spain (the Batasuna case). Ballot. Rio de Janeiro: UERJ. Volume 1 Número 1 Junho 2015. pp. 01-20. Disponível em: [http://www.e-publicacoes.uerj.br/ index.php/ballot]

\section{c) (i)(2)}

A Revista Ballot está licenciada sob uma licença Creative Commons Atribuição - Não Comercial - Compartilha Igual 3.0 Não Adaptada. 